\title{
RAISING HYPERTENSIVE PATIENTS' CONSCIOUSNESS ABOUT TREATMENT COMPLIANCE 1
}

\author{
Annelita Almeida Oliveira Reiners ${ }^{2}$ \\ Maria Suely Nogueira ${ }^{3}$
}

Reiners AAO, Nogueira MS. Raising hypertensive patients' consciousness about treatment compliance. Rev Latino-am Enfermagem 2009 janeiro-fevereiro; 17(1):59-65.

Descriptive study with qualitative approach that aimed to understand the perspective of health professionals and hypertensive patients on their mutual interaction in the public health context, so as to analyze how this interaction contributes to non-compliance with treatment. Interviews with 15 health professionals and 10 hypertensive patients who interacted in public health units were carried out. In the interaction between the health professional and the hypertensive user, it was concluded that, in order to solve the problem of noncompliance with treatment from the part of the user, the health professional makes use of awareness strategies. In practice, however, this has occurred inappropriately and under the biomedical care model. Users, in turn, have managed treatment their own way, indicating some issues to health professionals regarding compliance.

DESCRIPTORS: nurse-patient relations; physician-patient relations; hypertension; patient acceptance of health care; treatment refusal

\section{CONCIENTIZACIÓN DEL USUARIO HIPERTENSO SOBRE LA ADHESIÓN AL TRATAMIENTO}

Se trata de un estudio descriptivo cualitativo, cuyos objetivos fueron comprender la perspectiva del profesional de la salud y la del usuario hipertenso sobre la interacción que ocurre entre ellos en el contexto de la salud pública, y analizar el modo en que esta interacción contribuye para la no adhesión al tratamiento. La recolección de datos se realizó por medio de entrevistas semiestructuradas con 15 profesionales de la salud y con 10 usuarios hipertensos, que interactuaban en unidades públicas de salud en el municipio de Cuiabá, estado de Mato Grosso, Brasil. Se concluyó que en la interacción entre el profesional y el usuario, para resolver el problema de la no adherencia al tratamiento, el profesional usa la estrategia de concientizar al usuario sobre la situación. Sin embargo, esto se viene realizando guiado por el modelo biomédico de atención y de una manera inapropiada. A su vez, el usuario administra el tratamiento a su manera, lo que indica, a los profesionales, una serie de cuestiones relativas a la adhesión al tratamiento.

DESCRIPTORES: relaciones enfermero-paciente; relaciones médico-paciente; hipertensión; aceptación de la atención de salud; negativa del paciente al tratamiento

\section{CONSCIENTIZAÇÃO DO USUÁRIO HIPERTENSO PARA A ADESÃO AO TRATAMENTO}

Estudo descritivo de cunho qualitativo, cujos objetivos foram compreender a perspectiva do profissional de saúde e do usuário hipertenso sobre a interação que ocorre entre eles no contexto da saúde pública, e analisar de que forma essa interação contribui para a não adesão ao tratamento. A coleta dos dados foi realizada por meio de entrevistas semi-estruturadas com 15 profissionais de saúde e 10 usuários hipertensos que interagiam em unidades públicas de saúde do município de Cuiabá, MT. Concluiu-se que, na interação entre o profissional de saúde e o usuário hipertenso, para resolver o problema da não adesão desse último ao tratamento, o primeiro lança mão da estratégia de conscientização. Essa, no entanto, tem sido realizada ainda pautada no biomédico de atenção e de maneira inadequada. O usuário, por sua vez, em relação ao tratamento, o tem administrado à sua maneira, indicando aos profissionais de saúde algumas questões relativas à sua adesão.

DESCRITORES: relações enfermeiro-paciente; relações médico-paciente; hipertensão; adesão pelo paciente de cuidados de saúde; recusa do paciente ao tratamento

${ }^{1}$ Paper extracted from Doctoral Dissertation; ${ }^{2} \mathrm{Ph} . \mathrm{D}$. in Nursing, Faculty at Faculdade de Enfermagem da Universidade Federal de Mato Grosso, Brazil, e-mail: reiners17@hotmail.com; ${ }^{3}$ Ph.D. in Nursing, Faculty at Escola de Enfermagem de Ribeirão Preto, da Universidade de São Paulo, Centro Colaborador da OMS para o Desenvolvimento da Pesquisa em Enfermagem, Brazil, e-mail: msnog@eerp.usp.br. 


\section{INTRODUCTION}

Arterial hypertension (AH) is an important public health problem that is difficult to control for several reasons, among them non-compliance to treatment. In the world, despite the availability of effective treatments for hypertension, over half the patients abandon the treatment within one year after diagnosis; and, of those who remain under medical supervision, only $50 \%$ take at least $80 \%$ of the medication prescribed ${ }^{(1)}$. In Brazil, individual studies on treatment compliance show that hypertension control is around 20 to $40 \%$ and that the withdrawal rate sometime increases after beginning the treatment ${ }^{(2)}$.

In literature concerning users' treatment compliance/non-compliance, authors suggest that several factors may contribute to non-compliance. Many refer to the interaction between the health professional and the user as a factor that hinders treatment compliance, but without responding some of the following questions: How has interaction between the hypertensive user and the health professional been and to what extent has it encouraged non-compliance with treatment? Are there aspects of this interaction that have affected the users' behavior regarding treatment? What aspects of this interaction may be leading the user to noncompliance with treatment?

From these questions, a study was developed with the following objectives: (1) to understand the perspective of health professionals and hypertensive users on their mutual interaction, in the health care context of public health units, (2) to examine how the interaction between health professionals and hypertensive users contributes to non-compliance with treatment.

\section{METHOD}

This is a descriptive study, using a qualitative approach, using Symbolic Interactionism as the theoretical framework, focusing on social interaction and considering that people's actions originate from these interactions. The methodological framework was Grounded Theory, a qualitative data analysis method, developed based on the ideas of the adopted theoretical framework.
The research was performed in ten public health units providing primary and secondary care to hypertensive users in the city of Cuiabá, Mato Grosso state, Brazil. At these units, service is provided through the work of physicians, nurses, the nursing staff [assistants and technicians] and community health agents, some hypertension prevention and control actions, such as screening for hypertension, checking blood pressure levels, scheduling appointments, referrals and exams, medication supply, nursing consultation [held by some nurses] and occasional lectures to hypertensive patient groups. Although nurses were part of the health team at most units, in two of them, no nursing services were provided to hypertensive patients.

Fifteen health professionals participated in this study, who interacted with hypertensive patients: six nurses, six physicians, one nursing technician and two nursing assistants - with ages ranging between 29 and 54 years and training time between 3 and 30 years. There were five people in the group with no specific expertise and the others were specialized in different areas, such as cardiology, hematology and public health. The practicing time with hypertensive patients ranged from 6 months to 24 years.

Similarly, 10 hypertensive patients participated in the study, i.e. health unit users who had had been in touch (during care) with health professionals for at least one year,. They were adults, between 42 and 72 years old, 4 men and 6 women. Most were married or widowers. Among them, some were illiterate and some had completed high school. They were retired, freelance workers and housewives. They all knew about their hypertensive condition for a time ranging from 1 to 20 years, and most had been going under treatment since the first diagnosis.

Data collection was performed after the approval of the Committee of Ethics in Local Research from January to August of 2003. The data were obtained after participants had signed a free and informed consent term, through 25 semi-structured interviews at the home or workplace of the participants. The tool used in this study was previously tested with a nurse, a physician and a user, containing an open questions script about the actions of health professionals and users while interacting, how the interaction occurred and their ideas about them, treatment and compliance / non-compliance. The interviews were finished when the theoretical saturation point was achieved. 
The data were processed, analyzed and interpreted, using the Grounded Theory procedures, developed in a process of comparisons, relationships and integration, until central categories were found around which and with which all other categories and subcategories were inter-related. Altogether, six categories (two central) and twenty-two subcategories were found.

Comparative analysis of the data contained in the categories and subcategories, interpreted in the light of the theoretical framework, existing literature on the subject and the practice of researchers were factors that enabled the formulation of a theoretical proposition. It demonstrated the understanding about the interaction between the user and the health professional, from which the elements were extracted to analyze the contribution of this interaction for treatment compliance.

The group of six categories found is represented in Figure 1, where two central categories (awareness and managing treatment your own way) were highlighted.
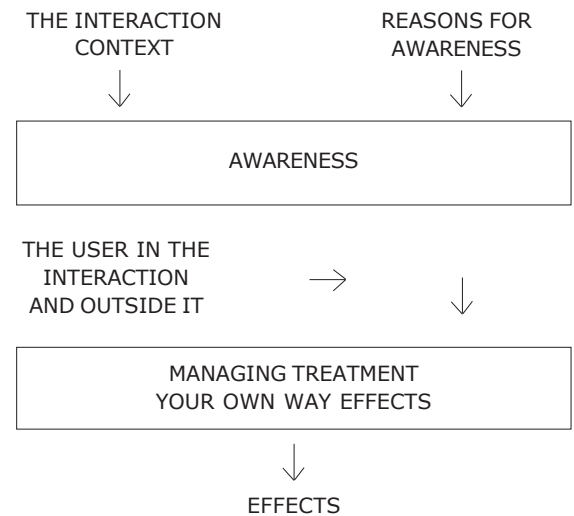

Picture 1 - Theoretical proposition about the interaction between the health professional and the user

In this article, the two central categories and their relationship with users' non-compliance with treatment will be presented and discussed.

\section{RESULTS AND DISCUSSION}

Health professionals* act in the interaction according to their perspectives, ideas, conceptions about users, relationships with them, about the disease $(\mathrm{AH})$ and the treatment, as well as treatment compliance and non-compliance. Similarly, users act in and outside the interaction, according to the meanings, perceptions, concepts and perspectives they have on $\mathrm{AH}$, the treatment, health professionals and their relationship, and treatment compliance and non-compliance.

From subject reports, it was understood that the interaction is still focused on techniques and tasks, prioritizing prescriptive routine actions, focused on the body, the illness, the process and the compliance - I perform nursing appointments. We start by checking the blood pressure, we check the blood pressure. While interacting with the patient, we ask if he is hypertensive. If he takes his medication. Since when. And if he was instructed as to his diet. We provide continuous monitoring, always checking the blood pressure, because that person has to have hypertension monitoring on a weekly basis or every two days, we check the pressure, and always keep in touch with him to prevent any sequelae ( $P$ 15).

This type of interaction is nothing more than playing the traditional biomedical model of health care that has been repeated over the years, even with the advent of new ways of care delivery to people with chronic health problems. Despite the considerable advances in many areas of medicine, which have occurred since the $19^{\text {th }}$ century, the human, experiential, psychological and cultural dimensions of disease have been neglected ${ }^{(3)}$.

The interaction driven by this model is characterized by its lack of balance and asymmetrical and unequal aspects, centered on the health care professional who performs the active role, the expert role, determining what the user can or cannot do with his body and health. The user, on the other hand, develops a passive role and, in most cases, is not given the opportunity to share or participate ${ }^{(4)}$.

In this study, during the interaction with users, health professionals believe that their ability to deal effectively with $\mathrm{AH}$ is hampered by the poor conditions of their work (low pay and limited availability of time, limited number of professionals) and by the fact that most users do not comply to treatment.

Health professionals bring their own assumptions when interacting with the patient, some of which have been internalized during their training process. One of these assumptions is: non-compliance with treatment is a misleading and irrational behavior of the patient and it needs to be corrected. 
Users who do not comply with treatment are considered difficult, complicated, inconsequential, but mainly stubborn and rebellious patients - Hey, there are some patients that we say: "This patient is rebellious, he can't accept it". (P 6). They are also considered as risk patients who do not follow recommendations as prescribed and do not believe in the severity of hypertension - some patients can't accept it, some patients, when you are talking to them, they think that it isn't true, that it is all a lie,... (P 6).

Studies show that, in general, professionals believe that patients act like that because they ignore the importance of treatment, due to their lack of education or simple disobedience of medical orders $^{(5-7)}$.

Since non-compliance with treatment is a problem that needs to be addressed, health professionals use a strategy to manage it, which consists of raising users' awareness about the importance of treatment.

\section{Awareness}

According to reports, health professionals consider awareness an educational activity that aims at making users aware of their health problem and learn what is needed to control it - (...) basically that, health education, awareness that complying to treatment is the best for him... (P 28).

It is a repetitive activity performed by talking to the user, and constantly urging that $\mathrm{AH}$ is serious, incurable, causing complications and even death, talking about the importance of treatment and compliance as a way to control the disease and prevent complications; and furthermore, emphasizing the risks if users do not comply with treatment.

Health professionals characterized the action of raising awareness with the words "trying to get it into their heads", "put in the mind of the patient" and "make up his mind" - the patient who has an irregular treatment, shows much more manifestation of this chronic disease than the patient who treats it correctly. ...So, you just know that, with this one, you have to try to get into his head that he must take the disease seriously, because otherwise he will die, that it will complicate as time goes by, in the midterm and that, if he does not value the treatment, not follow the guidelines, he will have serious complications and have a, shall we say, much lower life expectancy (P 10).

In order to convince users to comply, various forms of communication are used by health care professionals regarding awareness. They range from having fun to making threats. Some of them draw the attention of the user, some use moral arguments, scold the user about it, frighten, dramatize or call upon the emotional, with the rhetoric that they are doing this for their sake. There are still others who believe the only resource is to be more authoritarian and threatening - It is a shock treatment, I think. So from the moment you show the risks: "Look, if you don't follow the treatment, these are the risks and they can happen to you. It happened to your neighbor, happened to my mother ... " Got it? Suddenly, you make him more aware. I see it this way. If I could bring everyone to the emergency room just for a spin, they'd get out of there convinced, for sure ... (P 28).

In fact, health education is a fundamental element in the task of promoting the users' treatment compliance. However, it is noted that the idea that health professionals have about awareness in this study is based on the traditional model of education, on the bank concept of education ${ }^{(8)}$, seeing the teacher as its undisputed agent, whose task is to "fill" [author's emphasis] students with the contents of his narration. This concept is characteristic of people who teach and believe that knowledge is a gift from the wise to those who, according to them, know nothing and passively receive the knowledge derived from their professional authority.

This is not new. Concepts regarding health education for nurses, nursing assistants, physicians and dental surgeons, in general, show a traditional way of perceiving it, and words like passing knowledge on and the expression transferring knowledge are often used $^{(9)}$

Taking this information into consideration, health professionals assume that their knowledge is greater than the popular knowledge that usually comes from personal experiences and beliefs ${ }^{(10)}$. They take advantage of their condition, of having a more privileged training, and take full control of hypertension knowledge and management, aiming to change the way users think and act to the way they themselves think and act [or would act]. Health professionals, under the aegis of science, believe they may hold control over users' body, health, life and death, denying users the benefit of change, discussion and the thorough knowledge of their condition.

Health professionals, hence, assume the task of giving, delivering, carrying and transmitting knowledge to the user, believing that it is enough to promote behavior changes. This is a mistake, since behavior is not mutable by a purely pedagogical 
relationship or personal advice. Moreover, change is not effective if inappropriate means of communication are used, not considering the different forms and rates of the users' knowledge apprehension. On the contrary, it is the result of psychological conditioning and actual relationships at work, at home, leisure, among others ${ }^{(11)}$.

Accordingly, professionals no longer consider and address the issue of non-compliance properly, which is complex and determined by multiple factors. "Awareness" [author's emphasis] ends up being only one set of information on hypertension treatment passed on to users, whose connection with these persons and their lives lies only in the fact that they have the disease and holds the greatest responsibility to comply. Furthermore, users and their difficulties and weaknesses to comply are disregarded. As subjects of compliance, and the center of attention, users are neglected and not seen as people who can exchange ideas and experiences. In addition, they are not considered able to make free choices and autonomous to manage their health problem and treatment. Health care professionals fail to consider them as active members in the process of health care, as mature adults able to establish an agreement to, together, achieve progress in the therapeutic process.

But, just like health professionals are guided by their beliefs and concepts to make users aware of the need to comply with treatment, they also express their subjectivity. Inside and outside the interaction, users show that, when facing the reality of the treatment and all its implications, they develop their own strategies for coping with the disease and the therapeutic procedure.

Managing the treatment on their own

This category shows that, despite health professionals' effort to perform general health care actions toward hypertensive patients and raise awareness, users do not comply with treatment exactly as recommended. Most patient actions reveal that they have their own way to comply with treatment, with a personal way of managing it.

Generally, users participating in this research, although they do not like the treatment regimen since it brings many changes into their lives, consider that the treatment should be followed. Thus, in the beginning, they try to follow it strictly. They try to change their eating habits, get used to exercising, take medication regularly, and quit smoking, among other changes. But, as time goes by, many of these attempts failed and most decide to follow the treatment on their own, considering what can or cannot be done or even what they want to do.

Managing the treatment on their own comprises actions like deciding not to take any medication or take it only when symptoms appear, manipulating the prescribed times, choosing activities that are more pleasant, using alternative practices, deciding to stop the treatment, among others - In the beginning I felt some difficulty because I wanted to follow the medical recommendation too strictly. I lost much weight because I changed my way of eating and everything ... I started to lose weight. Then, I started giving up a little and went into the same old pace to my old routine. I saw that, with the medicine, by blood pressure was under control, so I'm not following it much. I'm just watching the salt a little bit. I don't strictly follow it, but I follow it (U 21).

The fact that users manage the treatment on their own is not new, because studies have shown it is frequent ${ }^{(12-15)}$. Patients adapt the treatment to their social habits, and when it conflicts with their individual welfare, they allow for certain indulgences in order to minimize the impact of these strict standards and rules.

The appearance of this category suggests some indications. It seems that, for users, even when convinced about the need to comply with the determinations of the professional for better health conditions, there is still a strong need to adapt the prescription, finding other, non-painful ways to follow the treatment.

Perhaps this result points at a way in which users resist against health professionals' measures, as an attempt to preserve their autonomy. This resistance is not strategically calculated or planned, but rather a defensive reaction against the invasion or infringement of their autonomy ${ }^{(16)}$ and freedom to have some control over their health and life, since, in the interaction space, this control is not in their hands.

The decision-making process of individuals with chronic health problems reflects the result of conscious decision to control the management of their disease and subsequent efforts to assume such control. To control means being able to mediate the effects of the disease, so that one can live as normal as possible $\mathrm{e}^{(14)}$ 
Another possible conclusion is that users may not know how to deal with this disease and treatment, which shows they lack or have insufficient knowledge, skills and abilities required to comply. Living with $\mathrm{AH}$ is not easy and treatment compliance is a complex process involving various biological, social and emotional factors, as well as practical and logistics ${ }^{(17)}$ barriers, such as knowing how to manage medication time and dosage, type of diet, the balance between activity and rest, blood pressure monitoring, learning alternatives, among other actions, which are dynamic, complex and at the same time challenging tasks.

By managing the treatment on their own, users may even be pointing at the fact that they and the health professionals understand the treatment differently. Generally, health professionals believe that their recommendations should be strictly followed [since they are based on behavior standards preestablished in official documents]. Users appear to believe that some failures are not harmful to treatment - since the treatment is long, a few days without taking medication does not alter the results in the process of healing(18).

The therapeutic treatment is at the same time concrete, in other words, composed of scientifically consolidated measures, and somewhat abstract when applied to users' lives. This happens because the meaning the measures have for them are not the same for health professionals - the ones prescribing it. When prescribed, the treatment is definitely outside the persons' life context [even if some items are already part of their daily lives, they do not have the same purpose], and therefore is not concrete. For some time, perhaps a long time, it will be abstract, until, in the process itself, it will become concrete.

Finally, another conclusion is that the interaction between users and health professionals is not appropriate, preventing problems not only related to their disease or their body from being discussed, but also those relating to their process of life and health. The reasons that make people follow or disregard health professionals' therapeutic

\section{REFERENCES}

1. World Health Organization (WHO). Adherence to long-term therapies: evidence for action. Geneva: WHO; 2003.

2. Sociedade Brasileira de Cardiologia / Sociedade Brasileira de Hipertensão / Sociedade Brasileira de Nefrologia. V Diretrizes Brasileiras de Hipertensão Arterial. Campos do recommendations bring to light the context they are inserted in and their integrity as human beings ${ }^{(19)}$.

\section{FINAL CONSIDERATIONS}

The two central categories found in this study and discussed in this article show that, in the interaction between health professionals and hypertensive users, to solve the issue of users' non-compliance, the former makes use of an awareness strategy. This, however, has been performed inadequately and based on biomedical care. Users, in turn, have managed treatment their own way, indicating some issues to health care professionals related to compliance.

It is believed that, similar to other studies ${ }^{(20-21)}$ on this theme, this research can collaborate to understand these aspects of interaction between health professionals and users. It may help nurses, physicians and other health professionals to rethink how to deal with users and the problem of noncompliance in their daily practice, using models and approaches aimed at helping them to improve compliance.

Accordingly, it is important that nurses understand that there is room to show technical and human competence through theories and approaches that increasingly emerge in the health field. It is also important to make a deep and developed assessment of user's health, which should include, from their perspective, their experience with the health problem and treatment, their difficulties, strengths and weaknesses. Moreover, there should be proposals for care based on solid scientific basis and appropriate to the health needs of the user. Finally, it is essential that nurses develop a profile of competences for this educational activity ${ }^{(22)}$, in which the objective is to contribute to increase users' care autonomy and capacity, also increasing their responsibility for their own health.
Jordão: 2006 .

3. Caprara A, Franco ALS. A relação paciente-médico: para uma humanização da prática médica. Cad saúde pública 1999; julho-setembro; 15(3):647-54.

4. De Valck C, Bensing J, Bruynooghe R, Batenburg V. Cureoriented versus care-oriented attitudes in medicine. Patient Edu Couns 2001; 45:119-26. 
5. Halett CE, Austin L, Caress A, Luker KA. Community nurses' perceptions of patient compliance in wound care: a discourse analysis. J Adv Nurs 2000; 32(1):115-23.

6. Maclean N, Phil B, Pound P, Wolfe C, Rudd A. The concept of patient motivation. Stroke 2002; 33:444-8.

7. Leite $\mathrm{SN}$, Vasconcellos MPC. Adesão à terapêutica medicamentosa: elementos para a discussão de conceitos e pressupostos adotados na literatura. Ciênc Saúde Coletiva 2003; 8(3):775-82.

8. Freire P. Pedagogia do oprimido. 17th ed. Rio de Janeiro: Paz e Terra; 1987.

9. Wendhausen A, Saupe R. Concepções de educação em saúde e a estratégia de saúde da família. Texto Contexto Enferm 2003; janeiro-março; 12(1):17-25.

10. Gropper RC. Cultural basics and chronic illness. Adv Ren Replace Ther 1998 April; 5(2):128-33.

11. Berlinguer G. Promoção da saúde. In: Berlinguer G. Questões de vida: ética, ciência e saúde. Salvador: APCEHucitec-Cebes; 1993. p. 149-59.

12. Dowell J, Hudson H. A qualitative study of medicationtaking behaviour in primary care. Fam Pract 1997; 14(5):369-75.

13. Gonçalves H, Costa JSD, Menezes AMB, Knauth D, Leal OF. Adesão à terapêutica da tuberculose em Pelotas, Rio Grande do Sul: na perspectiva do paciente. Cad Saúde Pública 1999; outubro-dezembro; 15(4):777-87.

14. Thorne S, Paterson B, Russell C. The structure of everyday self-care decision making in chronic illness. Qual Health Res 2003; December; 13(10):1337-52.

15. Broom D, Whittaker A. Controlling diabetes: moral language in the management of diabetes type 2. Soc Sci Med
2004; 58:2371-82.

16. Martins A. Biopolítica: o poder médico e a autonomia do paciente em uma nova concepção de saúde. Interface 2003 setembro - 2004; fevereiro; 8(14):21-32.

17. Jesus ES, Augusto MAO, Gusmão J, Mion Júnior D, Ortega K, Pierin AMG. Perfil de um grupo de hipertensos: aspectos biossociais, conhecimentos e adesão ao tratamento. Acta Paul Enferm 2008; 21(1):59-65.

18. Gonçalves HD. Corpo doente: estudo acerca da percepção corporal da tuberculose. In: Duarte LFD, Leal OF, org. Doença, sofrimento, perturbação: perspectivas etnográficas. Rio de Janeiro: Fiocruz; 1998. p. 105-17.

19. Stuchi RAG. Crenças dos portadores de doença coronariana sobre os comportamentos de risco. [Dissertação] Escola de Enfermagem de Ribeirão Preto: Universidade de São Paulo, Ribeirão Preto; 1999.

20. Backes DS, Koerich MS, Erdmann AL Humanizing care through the valuation of the human being: resignification of values and principles by health professionals. Rev. LatinoAm. Enfermagem 2007, 5(1):34-41.

21. Lyra Junior DP; Amaral RT; Veiga EV, Cárnio EC, Nogueira MS, Pelá IR. A farmacoterapia no idoso: revisão sobre a abordagem multiprofissional no controle da hipertensão arterial sistêmica. Rev. Latino-Am. Enfermagem 2006, $14(3): 435-441$.

22. Leonello VM. Competências para ação educativa da enfermeira. Rev Latino-am Enfermagem [periódico na Internet]. $2008 \mathrm{Abr}$ [citado 2008 Jul19]; 16(2): 177-183. Disponível em: http://www.scielo.br/scielo.php?script=sci_ arttext\&pid $=$ S0104-11692008000200002\&lng $=p t \& n r m=$ iso.doi: $10.1590 /$ S0104-11692008000200002. 